\title{
Development of Adaptive Sports Models in Improving Motor Ability and Embedding Cultural Values in Children with Special Needs
}

\author{
Rizqi Fajar Pradipta \\ Special Education Department \\ Universitas Negeri Malang, Indonesia \\ rizqi.fajar.fip@um.ac.id
}

\author{
Dimas Arif Dewantoro \\ Special Education Department \\ Universitas Negeri Malang, Indonesia \\ dimas.arif.fip@um.ac.id
}

\begin{abstract}
Adaptive physical education is education that provides opportunities for students with special needs to be able to actualize physical activities through activities that are directed and planned in the learning program. Development research is a method for producing certain products or perfecting existing products and testing the effectiveness of these products. Researchers conduct research and development of adaptive sports models. The feasibility level of developing this model is known through validation by the material expert, validation by the media expert, validation by the teacher and trial use by students. Learning to use adaptive sports models for children with special needs has a response that is quite positive and has a good impact. This is shown in the data exposure related to the results of the teacher's response of two people and five students during the implementation of the trial with the acquisition of an average value of 4.5 for teachers and 4.6 for students so that if within the range values > 4.2 "very good", thus the response results show "very good" results.
\end{abstract}

Keywords: adaptive sports; motor ability; cultural values

\section{INTRODUCTION}

Along with the rapid development of information and communication technology, globalization has also increasingly spread to all corners of the world. Its spread is rapid and widespread, not limited to developed countries with high economic growth, but also across the borders of developing and poor countries with low economic growth. The development of information and communication technology with the rapid flow of globalization are two interrelated processes. Both of them support each other. There is no globalization without advances in information and communication technology. The development of information and communication technology also runs slowly if people do not think globally.

In that context, globalization has become an inevitable phenomenon (Scholte 2001). All groups, like it or not, must accept the fact that globalization is a deadly virus that can adversely affect the fading of the existence of local cultures or a panacea that can cure traditional diseases rooted in laziness, ignorance, and backwardness. Because globalization is carried out by developed countries (read: West) which have different cultures from developing countries, Western values can be a threat to the preservation of local values in developing countries, including Indonesia.

Admittedly, the main actors in the current process of globalization are developed countries. They are trying to export local values in their countries to be spread throughout the world as global values. They can easily do that because they master the flow of information and communication technology across nation-state borders. Conversely, at the same time, developing countries are unable to spread their local values due to their low competitive power. As a result, developing countries only become spectators for the entry and development of developed country values that are considered global values into the territory of their country.

For Indonesia, the inclusion of Western values that hitched the tide of globalization among the Indonesian people was a threat to the native culture that imaged the locality typical of the regions in the country. Regional arts such as ludruk, ketoprak, puppet, gamelan and dance face a serious threat from the development of Western pop culture that is increasingly in demand by the public because it is considered more modern. Conventional culture that places tepo seliro, tolerance, hospitality, respect for older people is also attacked by free association and individualistic attitude brought by the current of globalization. In such situations, mistakes in responding to globalization can result in the disappearance of local culture. Mistakes in formulating strategies to maintain the existence of local culture can also result in local culture becoming increasingly abandoned by people who are now increasingly infatuated with the culture brought by the current of globalization.

This is the biggest problem of local culture in the present era. When the wave of globalization rolled over Indonesian territory, its strength was able to crush local cultures. According to Saidi (1998), the process has been going on since the start of the era of Indonesia's liberalization during the era of President Soeharto. Since the liberalization period, foreign cultures have entered Indonesia in line with the influx of other influences. Meanwhile, Mubah (2011) argues that cultural destruction began in the age of information technology such as satellite and the internet. Since that time, consumption of information has become increasingly unlimited. Unlawful times to consume something turns out to be halal for granted. Small children can just look at pornographic images. Teenagers who are supposed to be the cornerstone of the nation's culture even glorify hedonism and modernity.

The map contained the whole understanding, values, norms, science and overall social, religious structures, as well as all intellectual and artistic statements that characterize a society (Eppink in Soedarsono 1999). It also stores knowledge, beliefs, arts, morals, law, customs, and other abilities acquired by a person as a member of the community (Taylor in Soedarsono, 1999). Not surprisingly, Soemardjan and Soemardi (in Soedarsono, 1999) stated that culture is a means of people's work, taste, and creativity. Therefore, the importance of reinforcing traditional values not only leads to physical strengthening but also strengthens 
the sense of cultural love for the country in children with Special Needs through adaptive sports.

Children with special needs (ABK) need to be helped so that their strengths can be developed because children with special needs usually have advantages or potentials behind the shortcomings that exist in themselves. In order for children with special needs (ABK) to obtain their right to get good education services, the Government of Indonesia has facilitated special education for them as stated in the Law of the Republic of Indonesia Number 20 Year 2003 concerning the National Education System. This is stated in Article 32, Paragraph (1) which states that special education is education for students who have difficulty in following the learning process due to physical, emotional, mental, social, and / or potential disabilities and special talents. Furthermore, Article 5 (2) stipulates that citizens who have physical, emotional, intellectual and / or social disabilities are entitled to special education.

Special education is education for children with special needs $(\mathrm{ABK})$. This educational process requires individual planning and monitoring procedures for teaching are carried out systematically. Materials and equipment are adapted to the needs of children. The form of intervention is designed to help children with special needs achieve progress higher than before and take place in a sustainable manner. Such special educational characteristics require more specific efforts and resources compared to ordinary education.

Students with special needs need to get special learning services tailored to their conditions in each subject. Special Physical Education lessons (Physical Education) students with special needs need to get special services. This special service is called adaptive physical education. Adaptive physical education is education through physical activity programs that are modified to enable individuals with disabilities to have the opportunity to participate safely, successfully and obtain satisfaction (Hosni, 2003). Therefore, adaptive physical education is education that provides opportunities for students with special needs to be able to actualize physical activities through activities that are directed and planned in the learning program. Abdoellah (1996) also states that the majority of students with special needs have low mobilization capacity, and physical performance is lacking, therefore students with special needs have a greater need for movement, it is only natural that physical education should be the main program of the program education for students who have special needs as a whole, because it becomes the basis for the improvement of bodily functions that are needed.

\section{LITERATURE REVIEW}

According to Mangunsong (2009), ABK is a child who deviates from the average normal child in terms of mental characteristics, sensory abilities, physical and neuromuscular, social and emotional behavior, communication skills, or a combination of two or more of the above to the extent that it requires modification in school assignments, learning methods or other related services, aimed at developing its maximum potential or capacity. ABK can be grouped into two major groups according to the problems they face, namely the sensorimotor and learning problems or behavior. Sensorimotor problems are seen from the ability to see, hear, and move, and are more easily identified and do not have to have intellectual abilities problems; some of these children can learn and study well.

Sensorimotor abnormalities can be in the form of: (1) hearing impairment (hearing disorders); (2) visual impairment; and (3) physical disability. In developing its abilities, each type of disability needs to involve and collaborate with various specialists and teachers who have special skills and expertise as needed. ABK groups who experience problems in learning or behavior include: (1) intellectual disability; (2) special learning disabilities (learning disability); (3) tunalaras (behavior disorders); (4) gifted and gifted children; and (5) multiple handicaps. The adaptive game learning intended in this study is directed towards children with special needs who experience sensorimotor problems, namely children who have hearing impairments, hearing impairments, visual impairments, and physical or visual impairments.

Each type of disruption or problem faced by ABK requires different services. Likewise, in adaptive physical education, each type of disorder requires its own form of physical education services. Therefore, ideally the adaptive physical education program is an individual service program. In learning, there is a process of interaction or two-way communication between teacher and child where the teacher acts as an educator and the child as a student (Sagala, 2009). The interaction of both aims to develop children's potential as students, and good development starts with what the child can do, not what he cannot do. Related to potential development, Edy (2014) revealed the explanation of Stephen Covey, author of The Seven Habits of Highly Effective People, saying that "don't focus on what you can't reach, don't focus on what you think, but focus on what that can be reached and done.

Related to this way of achievement, Edy always believes that if Indonesian children are managed properly and well, they will surely succeed, because Indonesian children have the potential to become world class. The mistakes are in management, including the education system, the guidance system, the talent search system, and the motivation system (Edy, 2014). Sa'id (2015) rewrote the word Ali bin Abi Talib R.A. that “a person's value lies in what makes him experience the process of growth and improvement". He tells a story that has changed beliefs and made it a method for developing personality and being successful. It is said that there was a rabbit who went to school with his strengths in running and jumping, but the school did not pay attention to these advantages and forced him to learn to swim. Until the end of the school year, the rabbit made no progress in swimming and finally decided to get out of school with the ability to run and jump mediocre and did not get the slightest result in learning to swim. Birds that meet rabbits from the school say "I have never seen you not go to school, if for a year at school you learn to run and jump two hours a day, of course you will be the fastest rabbit and farthest jumper today". The meaning of this story is that in the development of children's abilities, it does not start from what cannot be done and not from what has no potential in him, but must be from what can be done and from the potential that exists in him.

Bill Rose's experience in carrying out her learning assignments needs to be taken into consideration in learning 
for ABK. Bill Rose as a teacher knows that his students have a fear of failure, and for that he starts his learning by "helping to accelerate success". Bill Rose goes on to say that "once they have succeeded" they will want to learn the next material (Lickona, 2013). Bill Rose's statement written by Lickona implies that the formulation of competencies that children must achieve is the first step in learning, and is a component that is generally taken in every learning model. Based on Bill Rose's experience above, identifying children's early abilities should be the first step in designing adaptive learning for children with special needs because the results of identifying initial abilities can be used as a basis and greatly help the teacher in setting goals to be achieved at a later stage. This is consistent with the opinion of Keller (2010) that a good understanding of the characteristics of children is very helpful for teachers in facilitating children to achieve learning goals.

In addition, according to Personal opinion (2011) that analysis of children's characteristics includes several important aspects, namely: (1) general characteristics, (2) specific competencies that have been previously owned by children, (3) learning styles or learning styles of children, and (4) motivation. In essence, learning game material must be able to know the extent to which children reach their abilities and then have to think about and even promote children's learning and development (Bennet, et al., 2005). Learning for ABK can be done through two strategies, namely accommodation and modification. Accommodation is a natural adjustment for teaching practices so that children learn the same material, but in a format that is accessible to children. Accommodations can be classified based on what they want to change; whether presentations, responses, settings, or scheduling (McLellan, 2007).

Accommodation according to Alabama State Department of Education (2014) is a change offered to students with disabilities to reduce the impact of disability in the learning environment. Accommodation relates to accessing services, reducing limitations, and removing obstacles so students can achieve the same goals as their peers. Accommodation allows students to complete the same tasks as other students, but allows changes in time, format, arrangement, scheduling, response, or presentation. In addition to accommodation, modifications can also be made, namely changes made to the training content. When the contents of the exercise are modified, students do not have to pursue the required content standards. Individual programs for students must be made by modifying content, gradations, and other forms of assessment. This activity actually changes to meet the unique needs of students with special needs, and adjusts to the expected assignment or test. From the description above it can be concluded that learning in physical education for children with special needs, especially in learning a game skill must be able to develop children's potential starting from what can be done by children so that the sense of achieving success can immediately arise. For this reason, accommodation and modification are needed in learning by adjusting and / or changing teaching materials so that children can achieve learning goals.

The opening of the 1945 Constitution mandates that the formation of the Government of the Republic of Indonesia is, among other things, to educate the nation's life. To realize this effort, the 1945 Constitution Article 31
Paragraph (3) instructs the Government to strive for and implement a national education system, which enhances faith and piety and noble character in the context of intellectual life of the nation, which is regulated by law. Embodiment of the mandate of the 1945 Constitution, namely the enactment of Law Number 20 of 2003 concerning the National Education System, which was the product of the first education law at the beginning of the 21 st century. This law becomes the legal basis for developing national education by applying the principles of democracy, decentralization, and educational autonomy that upholds human rights. Since the Proclamation of Independence on August 17, 1945, the law on the national education system has been amended several times.

National education, as one of the national development sectors in an effort to educate the nation's life, has a vision of the realization of the education system as a strong and authoritative social institution to empower all Indonesian citizens to develop into qualified human beings so that they are able and proactively respond to the challenges of the ever changing times. The meaning of qualified human beings, according to Law Number 20 Year 2003 concerning the National Education System, is educated people who believe and are devoted to God Almighty, of good morality, healthy, knowledgeable, capable, creative, independent, and become democratic citizens and responsible. Therefore, national education must function optimally as the main vehicle for nation and character development. The implementation of education as mandated in Law Number 20 Year 2003 concerning the National Education System is expected to realize the process of developing the personal quality of students as the next generation of the nation in the future, which is believed to be a determining factor for the development of the nation and state of Indonesia throughout the ages. Of the many elements of educational resources, the curriculum is one element that can make a significant contribution to realizing the process of developing the quality of potential learners.

So there is no denying that the curriculum, which is developed based on competence is needed as an instrument to direct students to become: (1) qualified human beings who are capable and proactive in responding to the challenges of an ever changing era; and (2) educated people who have faith and are devoted to God Almighty, noble, healthy, knowledgeable, capable, creative, independent; and (3) democratic and responsible citizens. The development and implementation of competency-based curriculum is one of the national education development strategies as mandated in Law Number 20 of 2003 concerning the National Education System.

Efforts to develop the identity of the Indonesian nation, including respect for cultural and linguistic values, values of social solidarity, kinship and a sense of patriotism, are increasingly fading. Local culture that is more in line with the nation's character is increasingly difficult to find, while global culture is easier to penetrate. So far, what has been netted by society is only a lifestyle that leads to westernization, not modern lifestyle. Therefore, national identity as a value of community identity must be built solidly and deeply internalized. How, by instilling the values of local wisdom early on to the younger generation. Education plays an important role here so cultural teaching needs to be included in the national education curriculum 
and taught since elementary school. It must be understood, the values of local wisdom are not obsolete values that are obsolete so that they are abandoned, but they can synergize with universal values and modern values brought by globalization.

The international world is demanding democracy, human rights, the environment into the development agenda in every country. These issues can synergize with the actualization of the cultural philosophy of 'hamemayu hayuning bawana' which teaches people to behave and behave that always puts harmony, harmony, harmony and balance in the relationship between humans and nature, humans and humans and humans with God in carrying out life and life so that the country becomes long, arbor, gemah ripah loh jinawi, karta tur raharja (Suryanti, et al, 2008). Hamemayu hayuning bawana can be realized with 'hamemasuh memalaning Bumi', which is cleaning or securing actions that violate human rights. "Cutting the Earth" can be in the form of warfare, ethnic abolition, drug abuse, use of weapons of mass destruction, terrorism, disease outbreaks, burning of forests, and others that endanger human life and the natural environment. Western ratios and creativity can synergize with 'hangengasah mingising mind', which illustrates the endless efforts to sharpen mind / person so that it becomes sharper over time.

Human beings who are honed will always produce things that are good and even noble in the form of desire to the actions or works (Suryanti et al, 2008). In this case, it is expected that humans can give birth to thoughts or desires that are good or noble continuously in order to be donated for the benefit of humans or great, including to protect or preserve the whole world. Work ethic and professionalism can be synergized with the philosophy of 'lonely strings attached rame ing gawe' (work hard without thinking of yourself). The establishment of peaceful conditions in establishing relations with other countries so as to create security stability from the sub regional, regional and even world levels should be achieved with the application of the concept of 'walking without reinforcements, menang tanpo ngasorake' (Suryanti et al, 2008).

Inevitable globalization must be anticipated with cultural development characterized by the strengthening of identity and local wisdom that serve as the basis for developing strategies for the preservation and development of culture. Efforts to strengthen regional identity can be done through the inculcation of cultural values and the historicity of the same fate among the residents. Therefore, it is necessary to revitalize regional culture and strengthen regional culture. Cultural development that is characterized by strengthening self-identity has the character and nature of interdependence or interdisciplinary, spatial, multidimensional, interdisciplinary structural dependence on the community as a basic strength by utilizing the potential of high equity resources. The character of cultural development effectively embraces and moves all elements in facing the era of globalization which opens cross-cultural (transcultural) and cross-cultural (cross-cultural) processes that will continually bring together cultural values with one another (Saptadi 2008).

Physical development is very closely related to the motor development of children. According to Endah, motor is the development of controlling body movements through coordinated activities between the nervous system, muscles, brain and spiral cord. Motor development includes gross and fine motor skills. Gross motor is a body movement that uses large muscles or most or all members of the body that are affected by the child's own maturity. For example, the ability to sit, kick, run, go up and down stairs and so on. Whereas fine motor is a movement that uses fine muscles or certain parts of the body, which is influenced by the opportunity to learn and practice. For example, the ability to move objects from hands, scribble, arrange blocks, cut, write and so on. Both of these abilities are very important so that children can develop optimally.

In the development of children, according to the Director General of Sport motor skills can be divided into two enrichments, as follows:

a. Gross motor enrichment is the ability of preschoolers to move by using large muscles. The ability to use large muscles for children with special needs is classified as basic mobility. This ability is done to improve the quality of life of children. Basic mobility is divided into three categories, namely locomotor, non-motomotor and manipulative.

1) Non-motomotor Ability

Non-motomotor capabilities are performed on-site, without adequate room for movement. Non-motomotor capabilities consist of bending and stretching, pushing and pulling, lifting and lowering, folding and turning, shaking, circular, bouncing and so on.

2) Locomotor Capability

The locomotor's ability is used to move the body from one place to another or to lift the body up, such as jumping and jumping. Other movement abilities are walking, running, skipping, jumping, gliding and running like a galloping horse.

3) Manipulative Skills'

Manipulative abilities are developed when children are mastering various objects. Manipulative abilities involve more hands and feet, but other parts of the body are also used. The object manipulation is far superior to the coordination of the ankles and the eyes of the hand. Coordination is quite important for the process of running in space. The forms of manipulative abilities consist of pushing (throwing, hitting and kicking) movements, receiving (capturing) objects. This movement can be taught by using a ball made of rubber bundles (medical balls) or plastic balls with bouncing or bouncing ball movements.

b. Enriching fine motor skills is the ability of preschoolers to move by using small (small) muscles, such as writing, squeezing, grasping, drawing, arranging blocks, and inserting marbles into holes

Motor ability is the ability of a person to display motion until more complex. This ability is a general ability of a person related to various abilities or tasks of motion. 4 Thus, motor ability is the ability of one's motion in carrying out all activities. In line with the above, fine motor movements have a very important role. Fine motor is a movement that only involves certain body parts that are carried out by small muscles.

Therefore, movement in fine motor does not require energy but requires careful and meticulous coordination. According to the Director General of Sports, the principle of motor development of preschool children is a change, both physical and psychological, in accordance with the period of its growth. 
Motor development is strongly influenced by nutrition, health status and motor treatment according to the period of its development. The values obtained from motor development in children include gaining meaningful experience, rights and opportunities for activity, balance of body and soul, and being able to play a role in being themselves. The purpose and function of motor development is the mastery of the abilities depicted in the ability to complete certain motor tasks. Motor quality can be seen from how far the child is able to display motor tasks that are given with a certain level of success. If the level of success in carrying out motor tasks is high, it means that the motor does is effective and efficient.

\section{METHOD}

This research is a type of research and development or Research and Development (R\&D). According to Sugiyono (2010) research and development are research methods used to produce certain products, and test the effectiveness of these products. Sukmadinata (2007) defines research and development as a research approach to produce new products or improve existing products. So, development research is a method for producing certain products or perfecting existing products and testing the effectiveness of those products.

Researchers conduct research and development of adaptive sports models. The level of feasibility of developing this model is known through validation by the material expert, validation by the media expert, validation by the teacher and trial use by students. Borg \& Gall (in Sukmadinata, 2007) describes the ten steps of implementing the research and development strategy as follows:

1) Research and data collection (research and information collecting) which includes measurement of needs, study of literature, research on a small scale, and considerations in terms of value.

2) Planning (planning) that is compiling a research plan, including the abilities needed in conducting research, the formulation of objectives to be achieved with the research, design or research steps, and possibly within a limited scope.

3) Development of product drafts (develop preliminary form of product). Development of learning materials, learning processes, and evaluation instruments.

4) Preliminary field testing. Field trials in one to three schools with six to twelve test subjects (teachers). During the trial the observations, interviews and distribution of the questionnaire were carried out.

5) Revise the results of the trial (main product revision).

6) Main field testing. Conduct more extensive trials at 5 to 15 schools with 30 to 100 people testing subjects. Quantitative data on teacher performance before and after using the tested model was collected.

7) Improvement of product field test results (operational product revision).

8) Field implementation testing (operational field testing). Held in 10 to 30 schools involving 40 to 200 subjects. Testing is done through a questionnaire, interview, observation and analysis of the results.

9) Refinement of the final product (final product revision).

10) Dissemination and implementation (dissemination and implementation).
Research procedures undertaken by researchers in this development are adapted from the development steps developed by Borg \& Gall with limitations. Borg \& Gall (in Emzir, 2012) states that it is possible to limit research on a small scale, including limiting the research steps. The implementation steps are adjusted to the needs of researchers. Given the limited time and funds owned by researchers, the steps are simplified into four steps of development. The development steps undertaken by researchers are:

1) Data collection stage Data collection phase is carried out to determine learning needs in the field. The data collection stage is carried out by means of field studies and literature studies. a. Field studies were carried out to determine the need for model development in the field. Field studies are carried out by analyzing adaptive sports material applicable in schools, analyzing the stages of student development, and analyzing the availability of infrastructure in the field. b. Literature study of theories related to the development model of this adaptive sport.

2) Planning stage The planning phase starts with preparing the editorial team. Then the editorial team determines the design of the magazine. After the design of the magazine is determined, a mapping of learning material will be carried out. Mapping the material begins with the analysis of Core Competencies and Basic Competencies then proceed with the determination of the theme. At this planning stage an evaluation of the development model is also planned, namely by making an evaluation grid.

3) Product development stage The product development stage begins with the collection of studies of previous models, and other supporting models

4) The validation and trial phase of a development model that has been completed is then evaluated. The form of development model evaluation is validation. Validation is done in two stages. Stage I is validation by the material expert. The results of the revision of phase I are used for validation II by the teacher, suggestions from the teacher are used for revision II. The results of both revisions are used for student use trials.

Product trials are very important to be done to determine the quality of the resulting development models. Therefore, it is necessary to test the target of the product being developed. Before being tested, adaptive sports development model products are first validated by sports material experts and traditional cultural experts, then stage I revisions are made. Products that have been revised are validated by adaptive Physical Teachers, then stage II revisions are carried out. The second stage revision product was tested on 20 students with special needs.

The test subjects for the development of adaptive sports model are 20 students with special needs in Sidoarjo Regency. The selection of trial subjects was carried out randomly from the SMPLB level in Sidoarjo Regency.

Validation of material experts and adaptive sports material experts and traditional culture was carried out at Malang State University on the 4th Month of Week 2. Followed by validation by the Adaptive Physical Education Teacher at SLB Putera Mandiri Sidoarjo Regency 4th Month in the 3rd Week. Then proceed with the trial use by 
students with special needs at the Special High School level in Putera Mandiri Sidoarjo SLB in the 5th Month Week 1.

In accordance with the objectives of this development research, the data collected consists of two types, namely: (1) data regarding the process of developing adaptive sports models in accordance with predetermined procedures. This data comes from the assessment and input of adaptive material experts, experts / traditional cultural experts and adaptive physical education teachers; and (2) data on student responses to the development of adaptive sports models based on student use trials.

This study uses a data collection instrument in the form of a questionnaire regarding the feasibility of developing adaptive sports models for students with special needs. This questionnaire was prepared based on the criteria contained in the evaluation of the development of adaptive sports models. This questionnaire was made for adaptive sports material experts, traditional cultural experts, adaptive physical education teachers and students with different questionnaires according to their respective functions and interests.

This study uses descriptive data analysis with one variable, namely the quality of the development of adaptive sports models for students with special needs based on the criteria of good adaptive sports models that have been derived in the grading grid.

\section{RESUlt AND DiscuSSION}

This research and development aim to produce adaptive sports learning models for children with special hearing impairments and find out the feasibility of adaptive sports learning models for children with special hearing impairments. The learning model developed, was declared suitable to be used based on the validation by the material expert, the validation of the media expert, and the results of the trial by the teacher and student responses.

This developmental research refers to the development model and Borg \& Gall, which are limited to only a few stages. The stages include: a) the information gathering stage; b) planning stage; $c$ ) product development stage; and d) validation and testing stages. The following is an explanation of each stage carried out in this research and development:

1) Stage of information gathering

This stage begins with a literature review and literacy as well as the need to meet curriculum concepts related to growing culture in students with special needs at this time which began to be eroded by the era of digitalization in which began to lose some social aspects in an environment in society. In essence this sports learning model emphasizes more on how to foster togetherness in a learning process which in this case is like the spirit of working with friends around him.

2) The planning stage

The second stage consists of making a research instrument grid which becomes the evaluation criteria of the learning model. The instrument lattice that has been completed is then developed into a research instrument. The research instruments to be used are validation sheets, teacher user sheets, and student user sheets. The validation sheet is used to determine the feasibility of an adaptive sports learning model for children with special needs based on expert judgment on expert material. Material experts provide judgments based on material, learning, and linguistic aspects while cultural experts provide assessments based on aspects of cultural character. User response sheets are used to find out the responses and responses of teachers and students regarding the implementation of adaptive sports models for children with special needs.

3) Development stage

At this stage, a product in the form of adaptive sports learning model is made for children with special needs. The steps taken are: review syllabus and lesson plans. It aims to make it easier for researchers to conceptualize material in a structured way and not be separated from the available curriculum rules. The material in the adaptive sports learning model for children with special needs contains two main materials, namely games in developing gross and fine motor skills and improving aspects of character culture.

4) The validation and trial phase

Media validation phase is carried out so that the learning model of adaptive sports for children with special needs developed can be known for its worth based on the assessment of material experts and media experts. The validation of adaptive sports learning models for children with special needs is carried out by: (1) competent material experts in the field of learning for children with special needs; and (2) model development experts who are competent in the field of learning models. Data on the validation results of the material experts are presented in the appendix. The validated learning model products are then revised according to expert advice and input during the validation process. After the adaptive sports learning model has been revised, a trial phase for the use of the model in extraordinary school learning is carried out, which aims to determine the response of teachers and students to the adaptive sports learning model developed.

The trial phase was carried out at SLB Putra Mandiri Sidoarjo. The test is conducted by using the model in learning sports in schools by the teacher. After using the model, the teacher is directed to fill in the user response instrument (the teacher) to be asked for responses, suggestions, and comments about the developed model. In addition to the teacher, students are also directed to fill in the user response instrument (Student) to be asked for comments and comments about the developed model. The adaptive sports learning model that has been tested in schools has been revised based on suggestions and input from teachers and students.

The final result of this research and development is the Adaptive Sports Model in Improving Motor Ability and Instilling Cultural Values in Children Before conducting the trial, the adaptive sports model for children with special needs developed was validated in advance by the material expert. Material validation was carried out by lecturers of Special Education and Educational Technology, Faculty of Education, State University of Malang who had backgrounds in accordance with the material developed. Validation by material experts aims to get information, criticisms, and suggestions so that adaptive sports models for children with special needs are developed into quality products in terms of material, learning and linguistic aspects. The maximum score of each statement item in the validation sheet is 5 while the minimum score is 1 . The results of the material expert validation show the results of 
the average number of scores with a value of more than 4.2 "Very Good".

This research is a type of research and development. The results of this research and development are adaptive sports learning model products for children with special needs. There are several problems that lie behind the development of models in this study. These problems include: (1) not yet optimal sports learning in special schools; (2) lack of ability and willingness of teachers to develop appropriate adaptive sports models in learning; (3) the use of adaptive sports learning models in the learning activities has not varied; and (4) not many models and materials.

Research and development are carried out with reference to the stages of research and development according to Borg \& Gall. Borg \& Gall (1983) explained that there are ten stages in research and development, but in this research and development the ten steps are simplified into four steps. The factors that underlie the simplification are:

\section{a. Limited time}

If this research and development is carried out with ten stages it will require a relatively long and long process and time. Therefore, through simplification into four stages of research and development this is completed in a shorter time but still efficient and effective in the process and results.

b. Limited costs

A relatively large cost will be needed if this research is carried out in ten stages. Therefore, through simplification of the stages of this research can be completed with a relatively affordable cost.

c. The similarity of stages

Based on the ten stages of research \& development of the Borg \& Gall model, there are several stages that have a common goal. The similarity is seen in several stages, such as the preliminary field-testing stage, the main fieldtesting stage, and the operational field-testing stage. The similarity in the several stages of the trial, makes researchers simplify into one test phase that is after the revision of stage I. The similarity of objectives is also seen in the product revision stage so that researchers simplify into two stages of product revision namely after the product is validated and after the product trial.

d. The opinion of Borg \& Gall

Borg \& Gall (1983) suggest limiting research and development on a small scale, including limiting the steps of research in thesis and dissertation research. If you plan to do an R\&D project for a thesis or dissertation, you should keep these cautions in mind. It is best to undertake a smallscale project that involves a limited amount of original instruction design. Also, unless you have substantial financial resources, you will need to avoid expensive instructional media such as 16- $\mathrm{mm}$ film and synchronized slides. Another way to scale down the project is to limit development to just a few steps of the R\&D cycle ".

The four stages of research and development include: a. information gathering stage; b. planning stage; c. development stage; and d. validation and trial stages. This stage begins with a literature review and literacy as well as the need to meet curriculum concepts related to growing culture in students with special needs at this time which began to be eroded by the era of digitalization in which began to lose some social aspects in an environment in society. In essence this sports learning model emphasizes more on how to foster togetherness in a learning process which in this case is like the spirit of working with friends around him.

The second stage consists of making a research instrument grid which becomes the evaluation criteria of the learning model. The instrument lattice that has been completed is then developed into a research instrument. The research instruments to be used are validation sheets, teacher user sheets, and student user sheets. The validation sheet is used to determine the feasibility of an adaptive sports learning model for children with special needs based on expert judgment on expert material. Material experts provide judgments based on material, learning, and linguistic aspects while cultural experts provide assessments based on aspects of cultural character. User response sheets are used to find out the responses and responses of teachers and students regarding the implementation of adaptive sports models for children with special needs. At this stage, a product in the form of adaptive sports learning model is made for children with special needs. The steps taken are review syllabus and lesson plans. It aims to make it easier for researchers to conceptualize material in a structured way and not be separated from the available curriculum rules. The material in the adaptive sports learning model for children with special needs contains two main materials, namely games in developing gross and fine motor skills and improving aspects of character culture. The results of the material expert validation show the results of the average number of scores with a value of more than 4.2 "Very Good" and Very Eligible.

Media validation phase is carried out so that the learning model of adaptive sports for children with special needs developed can be known for its worth based on the assessment of material experts and media experts. The validation of adaptive sports learning models for children with special needs is carried out by: (1) competent material experts in the field of learning for children with special needs; and (2) model development experts who are competent in the field of learning models. Data on the validation results of the material experts are presented in the appendix. The validated learning model products are then revised according to expert advice and input during the validation process. After the adaptive sports learning model has been revised, a trial phase for the use of the model in extraordinary school learning is carried out, which aims to determine the response of teachers and students to the adaptive sports learning model developed.

The trial phase was carried out at SLB Putra Mandiri Sidoarjo. The test is conducted by using the model in learning sports in schools by the teacher. After using the model, the teacher is directed to fill in the user response instrument (the teacher) to be asked for responses, suggestions, and comments about the developed model. In addition to the teacher, students are also directed to fill in the user response instrument (Student) to be asked for comments and comments about the developed model. The adaptive sports learning model that has been tested in schools has been revised based on suggestions and input from teachers and students. The final result of this research and development is the Adaptive Sports Model in 
Improving Motor Ability and Instilling Cultural Values in Children with Special Needs. The results of responses from users in this case the teacher shows the results of the average number of scores with a value of more than 4.2 "Very Good" and very decent.

\section{Conclusion}

Based on the results of research data, it can be concluded that:

1. The research produces a product in the form of adaptive sports models for children with special needs that contain material, programs, and evaluations in learning adaptive sports in Extraordinary Schools

2. 2. Quality This adaptive sports model has been very valid because it has been validated by experts in their fields. Obtaining validation results in accordance with data exposure in the sub-results and discussion that displays the results of expert validation with a value of 4.6 with a range of values $>4.2$ is the same as "Very Good" and a descriptive assessment that is "Very Eligible"

3. 3. Learning to use adaptive sports models for children with special needs has a response that is quite positive and has a good impact. This is shown in the data exposure related to the results of the teacher's response of 2 (two) people and 5 (five) students during the implementation of the trial with the acquisition of an average value of 4.5 for teachers and 4.6 for students so that if within the range values $>4.2$ "very good", thus the response results show "very good" results.

The results of responses from users in this case the teacher shows the results of the average number of scores with a value of more than 4.2 "Very Good" and very decent. The results of responses from users in this case students show the results of the average number of scores with a value of more than 4.2 "Very Goo With the results of the research described above, it is necessary to do a number of things as a follow-up effort including:

1. The adaptive sports model that has been produced in this study can be used in sports learning in Extraordinary Schools.

2. Need to do similar research with more research subjects and a longer span of time, of course, with different student characteristics to obtain better results.

3. For further research it is necessary to develop other adaptive sports models so that it will enrich sports- related studies for students with special needs and very decent with Special Needs.

\section{REFERENCES}

[1] Abdoellah, A. (1996). Pendidikan Jasmani Adaptif. Jakarta: Departemen Pendidikan dan Kebudayaan Direktorat Jenderal Pendidikan Tinggi. Proyek Pendidikan Tenaga Akademik.

[2] Emzir, M., \& Pd, M. (2012). Metodologi Penelitian Kualitatif Analisis Data. Jakarta: Raja Grafindo.

[3] French, D. C., Eisenberg, N., Vaughan, J., Purwono, U., \& Suryanti, T. A. (2008). Religious involvement and the social competence and adjustment of Indonesian Muslim adolescents. Developmental psychology, 44(2), 597.

[4] Keller, T. (2010). Ministries of Mercy: The Call of the Jericho Road. Christianaudio.com.

[5] Lickona, T. (2013). Pendidikan Karakter: Panduan Lengkap Mendidik Siswa Menjadi Pintar dan Baik. Bandung: Nusa Media.

[6] Mangunsong, F. (2009). Psikologi dan pendidikan anak berkebutuhan khusus. Depok: LPSP3 UI.

[7] McLellan, D. (2007). Marxism after Marx. Hampshire: Palgrave Macmillan

[8] Mubah, A. S. (2011). Strategi Meningkatkan Daya Tahan Budaya Lokal dalam Menghadapi Arus Globalisasi. Jurnal Unair, 24(4), 302-308.

[9] Pribadi, B. A. (2011). Model ASSURE untuk Mendesain Pembelajaran Sukses. Jakarta: Dian Rakyat.

[10] Sagala, S. (2009). Kemampuan profesional guru dan tenaga kependidikan. Bandung: Alfabeta.

[11] Saptadi, K. Y. (2008). Membaca Globalisasi dalam Kaca Mata Perang Budaya. In Makalah Seminar Globalisasi, Seni, dan Moral Bangsa di Lembaga Ilmu Pengetahuan Indonesia (LIPI) Jakarta (Vol. 25).

[12] Scholte, R. H., Van Lieshout, C. F., \& Van Aken, M. A. (2001). Perceived relational support in adolescence: Dimensions, configurations, and adolescent adjustment. Journal of research on Adolescence, 11(1), 71-94.

[13] Soedarsono, R. M. (1999). Metodologi penelitian: seni pertunjukan dan seni rupa, dengan contoh-contoh untuk tesis dan disertasi. Masyarakat Seni Pertunjukan Indonesia.

[14] Sugiyono, P. Dr. 2010. Metode Penelitian Kuantitatif, Kualitatif, dan R\&D. Bandung: CV Alfabeta.

[15] Sukmadinata, N. S. (2007). Metode penelitian. Bandung: PT Remaja Rosda Karya.

[16] Susanto, H., \& Saidi, A. (1998). Klasifikasi masyarakat miskin. Puslitbang Ekonomi Dan Pemban.

[17] Usman, H. Dan Purnomo Setiady Akbar. 2011.”. Metodologi Penelitian Sosial”. Jakarta: Bumi Aksara

[18] Widoyoko, E. P. (2009). Evaluasi program pembelajaran. Yogyakarta: Pustaka Pelajar. 